\title{
Theory and Practice of Computation
}


This page intentionally left blank 


\section{Theory and Practice of Computation}

Proceedings of Workshop on Computation: Theory and Practice WCTP2013

University of the Philippines Diliman, Philippines

30 September - 1 October 2013

\section{Editors}

\section{Shin-ya Nishizaki}

Tokyo Institute of Technology, Japan

Masayuki Numao

Osaka University, Japan

Jaime 0 L Caro

University of the Philippines Diliman, Philippines

Merlin Teodosia [ Suarez

De La Salle University, Philippines 


\section{Published by}

World Scientific Publishing Co. Pte. Ltd.

5 Toh Tuck Link, Singapore 596224

USA office: 27 Warren Street, Suite 401-402, Hackensack, NJ 07601

UK office: 57 Shelton Street, Covent Garden, London WC2H 9HE

\section{British Library Cataloguing-in-Publication Data}

A catalogue record for this book is available from the British Library.

\section{THEORY AND PRACTICE OF COMPUTATION \\ Proceedings of Workshop on Computation: Theory and Practice (WCTP2013)}

Copyright (C) 2015 by World Scientific Publishing Co. Pte. Ltd.

All rights reserved. This book, or parts thereof, may not be reproduced in any form or by any means, electronic or mechanical, including photocopying, recording or any information storage and retrieval system now known or to be invented, without written permission from the publisher.

For photocopying of material in this volume, please pay a copying fee through the Copyright Clearance Center, Inc., 222 Rosewood Drive, Danvers, MA 01923, USA. In this case permission to photocopy is not required from the publisher.

ISBN 978-981-4612-87-6 


\section{CONTENTS}

Preface ix

Organizing Committee xi

Call-by-Name Evaluation of RPC and RMI Calculi 1

S. Araki and S. Nishizaki

Notes in Delays and Bisimulations of Spiking Neural P

Systems Using SNP Algebra

H. N. Adorna, K. C. Buño and F. G. C. Cabarle

Probing the Hardness of the Approximate Gene Cluster

Discovery Problem (AGCDP)

G. S. Cabunducan, J. B. Clemente, H. N. Adorna and R. T. Relator

Weak Bisimulation Between Two Biogeochemical Cycles

J. B. Clemente, H. N. Adorna and J. J. S. Villar

A Simulation of Transition P Systems in Weighted Spiking Neural P Systems

R. A. B. Juayong, N. H. S. Hernandez, F. G. C. Cabarle and H. N. Adorna

Robustness Analysis on Human-made Faults in Procedural Manuals

N. Nagatou and T. Watanabe

Compositional Construction of Group-wide Meta-level Architectures

T. Watanabe 
An Application Programming Interface for the

Communication and Storage Protocol for the TALA

Empathic Space

G. Cu, J. M. R. Cipriano, M. J. Gonzales, K. M. Tanalgo, C. K. B. Magdaong, M. P. Tiu and J. R. U. Longalong

An Object-oriented Language for Parameterised Reactive

System Specification based on Linear Temporal Logic

K. Osari, T. Murooka, K. Hagiwara, T. Ando, M. Shimakawa, S. Ito, S. Hagihara and N. Yonezaki

Building Policies for Supportive Feedback in Self-Directed Learning Scenarios

P. S. Inventado, R. Legaspi, K. Moriyama, K. Fukui and M. Numao

Data Collection with Prioritization for Wireless Sensor Networks

A. V. Ong and G. Cu

Health Information Search Personalization with Semantic

Network User Model

I. Puspitasari, K. I. Fukui, K. Moriyama and M. Numao

Learning English Words via Animations and Making

Sentences using an Etymological Memorization Method

K. Sumi and A. Kazuhara

A Serious Game Stimulating Children's Interest in Chemical Bonding

K. Sumi and K. Kudo

Development of a Visual Debugger for C Implemented in JavaScript 208 A. Nagae and K. Kagawa

Flash Code with Dual Modes of Encoding

M. J. Tan, P. Fernandez, N. A. Salazar, J. Ty and Y. Kaji 
Ranking Analysis of Battle Result of Board Game Strategy in Java Programming Exercise

K. Yamada and H. Tominaga

Distributed Inference to Support Inter-Subjective Empathic Computing

M. Numao

Author Index 
This page intentionally left blank 


\section{PREFACE}

Computation should be a good blend of theory and practice. Researchers in the field should create algorithms to address real world problems putting equal weight to analysis and implementation. Experimentation and simulation can be viewed as yielding to refined theories or improved applications. WCTP2013 is the third workshop organized by the Tokyo Institute of Technology, The Institute of Scientific and Industrial Research-Osaka University, University of the Philippines-Diliman and De La Salle University-Manila that is devoted to theoretical and practical approaches to computation. It aims to present the latest developments by theoreticians and practitioners in academe and industry working to address computational problems that can directly impact the way we live in society. Following the success of the Workshop on Computation: Theory and Practice 2011 (WCTP 2011), held in University of the Philippines Diliman, Quezon City, on September 2011, and of WCTP 2012, held in De La Salle University-Manila, on September 2012, the main and satellite conferences of WCTP 2013 are held both in University of the Philippines Diliman, on September 30 and October 1, 2013 and in University of San Jose-Recoletos, Cebu, on September 28 and 29, 2013.

This post-proceedings is the collection of the selected papers that were presented at WCTP 2013.

The program of WCTP 2013 was a combination of an invited talk given by Prof. Takashi Washio (Osaka University), and selected research contributions. It included the most recent visions and researches of the invited talk and 18 contributions. We collected the original contributions after their presentation at the workshop and began a review procedure that resulted in the selection of the papers in this volume. They appear here in the final form. 
WCTP 2013 required a lot of work that was heavily dependent on members of the program committee, and lastly, we owe a great debt of gratitude to the Tokyo Institute of Technology, specifically, its Philippines Office, which is managed by Ronaldo Gallardo, for sponsoring the workhop.

December, 2013

Shin-ya Nishizaki

Masayuki Numao

Jaime Caro

Merlin Teodosia Suarez 


\section{PROGRAM CO-CHAIRS}

Shin-ya Nishizaki

Masayuki Numao

Jaime Caro

Merlin Teodosia Suarez
Tokyo Insitute of Technology, Tokyo, Japan

Osaka University, Osaka, Japan

Univeristy of the Philippines - Diliman, the Philippines

De La Salle Univeristy - Manila, the Philippines

\section{PROGRAM COMMITTEES}

Tobias Mömke

Miguel A. Gutiérrez-Naranjo

Gabrial Ciobanu
- Saarland University, Germany

- University Seville, Spain

- the Romanian Academy of Science, Romania

Satoshi Kurihara, Koichi Moriyama, Ken-ichi Fukui,

- Osaka University, Japan

Ryutaro Ichise

- National Institute of Technology, Japan

Mitsuharu Yamamoto

- Chiba University, Japan

Hiroyuki Tominaga

- Kagawa University, Japan

Naoki Yonezaki, Takuo Watanabe, Shigeki Hagihara

- Tokyo Institute of Technology, Japan

Raymund Sison, Jocelynn $\mathrm{Cu}$, Gregory $\mathrm{Cu}$, Rhia Trogo,

Judith Azcarraga, Ethel Ong, Charibeth Cheng

- De La Salle University, the Philippines

Rommel Feria, Henry Adorna, Prospero Naval

- University of the Philippines, the Philippines 
xii

John Paul Vergara, Mercedes Rodrigo

- Ateneo De Manila University, the Philippines

Allan A. Sioson

Ateneo de Naga University, the Philippines

Randy S. Gamboa

Univeristy of Southeastern

Philippines, the Philippines

\section{GENERAL CO-CHAIRS}

Hirofumi Hinode

Tokyo Tech Philippines Office, Tokyo Institute of Technology, Japan

Kazuhiko Matsumoto International Collaboration Center, The Institute of Scientific and Industrial Research, Osaka

University, Japan

\section{ORGANIZING COMMITTEES}

Greg Gabison

Cherry Lyn Sta. Romana
University of San Jose Recoletos, the Philippines

Cebu Institute of Technology, the Philippines

\section{SECRETARIAT}

UP Information Technology Development Center 